\title{
腹腔鏡下スリーブ状胃切除術後に、 アルドステロン自律分泌が消失した一例
}

兵庫医科大学 糖尿病内分泌 - 免疫内科学 ${ }^{1)}$ 同 精神科神経科 ${ }^{2)}$ 同 上部消化管外科 ${ }^{3)}$

玉井 宏介 ${ }^{1)}$ 森本 晶子 $^{1)}$ 木俵 米一 ${ }^{1)}$ 八木千佐子 ${ }^{1)}$ 角谷 美樹 $^{1)}$

松尾 俊宏 ${ }^{1)}$ 三好 晶雄 ${ }^{1)}$ 角谷 学 ${ }^{1)}$ 吉村 知穂 ${ }^{2)}$ 倉橋 康典 ${ }^{3)}$

篠原 尚 ${ }^{3)}$ 小山 英則 ${ }^{1)}$

\section{まえがき}

肥満は脂肪組織が過剩に蓄積することによって、様々 な代謝異常(耐糖能異常、脂質異常症、高血圧など)を引 き起こすことがしられている。特に、日本人では皮下脂 肪の蓄積が相対的に少なく、内臓脂肪や脂肪組織以外に 脂肪が蓄積する異所性脂肪が蓄積しやすいことから、軽 度の肥満でも代謝異常を併発しやすいとされている。本 邦での肥満患者は増加傾向にあり、適切な体重管理が重 要な課題となっている。また、二次性高血圧の代表疾患 である原発性アルドステロン症(PA)に扔いても、その 病態に肥満が関与する可能性が報告されており、肥満の 合併の有無はPAの診断・治療において考慮すべき因子 と考えられる。体重管理としては食事・運動療法が大前 提となるが、高度肥満症に対しては外科手術の有効性が 報告されている ${ }^{1)}$ 。我々は、外科手術による肥満の是正 により塩化ナトリウム負荷に対するアルドステロン自律 分泌の消失を確認した一例を経験したので報告する。

\section{1. 症例}

【患者】 49 歳女性

【主訴】高度肥満症

【既往歴 / 併存疾患】脂質異常症

【家族歴】父 ; 高血圧、糖尿病 母; 狭心症 父方祖父；脳梗塞 肥満の家族歴なし

【生活歴】喫煙; Post $(20$ 本 $\times 27$ 年 $) 、$ 飲酒 ; なし

\section{【現病歴】}

$\mathrm{X}$ 年に近医で高度肥満(体重 $95.4 \mathrm{~kg} 、 B M I 35.5 \mathrm{~kg} / \mathrm{m}^{2}$ ) の精査を受けた際に、低レニン性高アルドステロン血症 (PRA 0.6ng/ml/hr、PAC $188 \mathrm{pg} / \mathrm{ml}$ ) を指摘された。高 血圧の既往はなく、低 K 血症、副腎腫瘍の合併は認め なかった。機能検査においては、カプトプリル負荷試験 および立位フロセミド負荷試験は陰性であったが、生食 負荷試験は陽性(負荷後 PAC 76.9pg/ml) を示したことか ら(表 1)、PA として抗アルドステロン薬(スピロノラク トン $25 \mathrm{mg} /$ 日) が開始された。肥満については原発性肥 満の診断で食事・運動療法が開始されたが、効果がそし かったため、X +1 年に当院へ紹介された。

\section{【人院時現症】}

身長 $165 \mathrm{~cm}$ 、体重 $96.5 \mathrm{~kg} 、$ BMI $35.4 \mathrm{~kg} / \mathrm{m}^{2}$ 、腹囲 $109 \mathrm{~cm}$ 、 意識清明、血圧 $125 / 69 \mathrm{mmHg}$ 、脈拍 62 / 分整、体温 $36.5^{\circ} \mathrm{C}$ 、甲状腺腫大なし、頸動脈雑音なし、胸部德診上 異常なし、腹部膨満・軟、両側前脛部・足背に浮腫あり、 両側足背動脈・後脛骨動脈触知あり

【常用薬】スピロノラクトン $25 \mathrm{mg} /$ 日、アムロジン $5 \mathrm{mg} /$ 日、 アゾセミド $15 \mathrm{mg} /$ 日

\section{【入院時検查所見】}

脂質異常症 (LDL-C 145mg/dl、TG $184 \mathrm{mg} / \mathrm{dl}$ ) と耐糖 能異常 (75gOGTT (120 分值) 170mg/dl)を認めた(表 2)。 また、二次性肥満を疑う所見は認めなかった。

\section{表 1. 内分泌学的検查所見}

\begin{tabular}{|c|c|c|c|c|c|c|c|}
\hline \multicolumn{3}{|c|}{$\begin{array}{l}\text { ※抗アルドステロン薬投与前date } \\
\text { 【血液】 }\end{array}$} & & \multicolumn{2}{|c|}{$\begin{array}{l}\text { カプトプリル } \\
\text { 負荷試験 }\end{array}$} & \multicolumn{2}{|c|}{$\begin{array}{l}\text { 立位フロセミ゙ } \\
\text { 負荷試験 }\end{array}$} \\
\hline PRA & $0.6 \mathrm{ng} / \mathrm{ml} / \mathrm{hr}$ & & Pre & $60 \mathrm{M}$ & $90 \mathrm{M}$ & Pre & $2 \mathrm{H}$ \\
\hline \multirow{2}{*}{ 【蓄尿】 } & $188 \mathrm{pg} / \mathrm{ml}$ & PRA & 0.7 & 0.8 & 0.7 & 0.7 & 2.2 \\
\hline & \multirow[b]{2}{*}{$11 \mu \mathrm{g} / \mathrm{day}$} & PAC & 158 & 133 & 95.8 & 144 & 629 \\
\hline Aldosterone & & ARR & 225.7 & 166.3 & 136.9 & & \\
\hline \multicolumn{8}{|c|}{ 【血液】※当院紹介時date } \\
\hline \multirow{3}{*}{$\begin{array}{ll}\text { TSH } & 0 \\
\text { Free } \mathrm{T}_{4}\end{array}$} & $663 \mu \mathrm{IU} / \mathrm{ml}$ & GH & \multicolumn{2}{|c|}{$\begin{aligned}<0.03 \mathrm{ng} / \mathrm{ml} \\
134 \mathrm{ng} / \mathrm{ml}\end{aligned}$} & DHEA-S & \multicolumn{2}{|c|}{$117 \mu \mathrm{g} / \mathrm{dl}$} \\
\hline & \multicolumn{3}{|c|}{ ACTH·Cortisol日内変動 } & \multicolumn{4}{|c|}{ デキサメタゾン抑制試験 } \\
\hline & 8 時 & 16時 & \multicolumn{2}{|c|}{23 時 } & $1 \mathrm{mg}$ & & \\
\hline $\mathrm{ACTH}$ & 19.3 & 17.9 & \multicolumn{2}{|c|}{7.3} & $<2.0$ & & \\
\hline cortisol & 7.03 & 3.00 & \multicolumn{2}{|c|}{1.30} & 0.28 & & \\
\hline
\end{tabular}

\section{表 2. 検査所見}

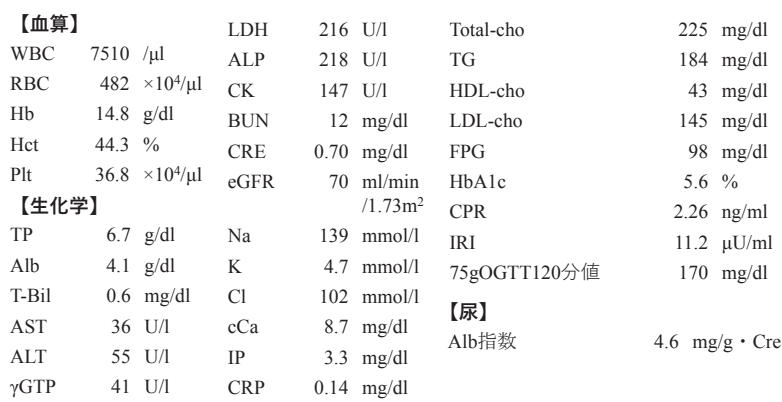

\section{【腹部 CT】}

脂肪肝および膵蔵の脂肪変性を認めた。副腎に明らか な腫大や腫瘍病変は認めなかった。著明な内臓脂肪の蓄 
積(内臓脂肪面積 $168.87 \mathrm{~cm}^{2}$ ) を認めた。

【アプノモニター検査】

AHI (無呼吸低呼吸指数) 11.2

【臨床経過】

【手術前】

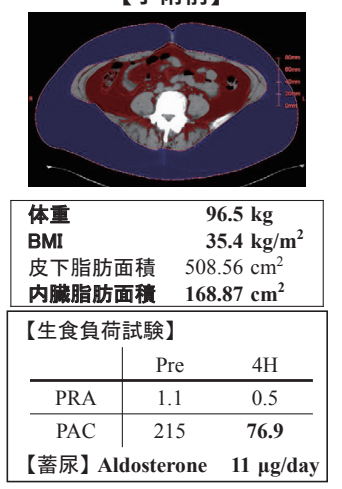

【手術1年後】

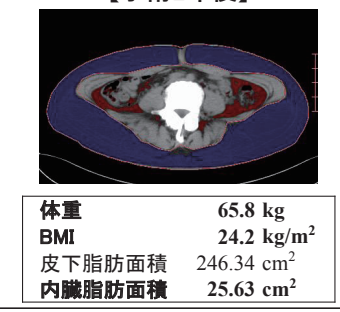

【生食負荷試験】※抗アルドステロン菓中止後

\begin{tabular}{c|cc} 
& Pre & $4 \mathrm{H}$ \\
\hline PRA & 0.3 & 0.2 \\
\hline PAC & 133 & $\mathbf{5 1 . 0}$ \\
【蓄尿】Aldosterone & $\mathbf{7 . 8} \boldsymbol{\mu g} / \mathbf{d a y}$
\end{tabular}

図 1. 治療経過

減量手術の適応基準(1) $18 \sim 65$ 歳の原発性肥満、(2) 6 力月以上の内科治療で有意な体重減少および肥満関連 合併症 (糖尿病、高血压、脂質異常症、閉塞性睡眠時無 呼吸症候群)の改善が得られない、(3)高度肥満症(BMI $\left.\geqq 35 \mathrm{~kg} / \mathrm{m}^{2}\right) ※ 2016$ 年 4 月版)を満たすことから、腹腔 鏡下スリーブ状胃切除術(LSG)を施行した。その後、体 重は速やかに減少していき、術後 1 年の時点で、体重 $64.6 \mathrm{~kg}(-30.7 \mathrm{~kg} /$ 年、体重減少率 $31.8 \%$ 、超過体重減 少率 $107.7 \%$ )、BMI $24 \mathrm{~kg} / \mathrm{m}^{2}$ 、内臟脂肪面積 $25.6 \mathrm{~cm}^{2}$ $\left(-87.1 \mathrm{~cm}^{2} /\right.$ 年) と体重および内臓脂肪量の著明な改善が 得られた。同時期にアルドステロンの自律分泌能の再評 価を行ったところ、生食負荷試験は陰性化(負荷後 PAC $51 \mathrm{pg} / \mathrm{ml}$ (図 1))しており、アルドステロンの自律分泌 は消失していると判断した。血圧管理については、アム ロジン $5 \mathrm{mg} /$ 日のみで良好なコントロールを得られてい たため、同量を継続とした。

\section{2. 考 察}

アルドステロンと肥満の関連については、以前より 様々な報告がなされている。本態性高血圧(Essential Hypertension; EHT)において PAC と BMI が正相関す ること ${ }^{2)}$ やメタボリックシンドローム $(\mathrm{MetS})$ の合併 率が EHT 44.8\%に対して PA 56.8\% と有意に高い ${ }^{3)}$ と いった肥満関連指標との相関が報告されている。近年で は、Karashima らより、年齢や血圧などが同じ EHT と PA では体重や BMI における差は認めなかったが、腹囲 と内臓脂肪量が PA で有意に高值であったとの報告があ る ${ }^{4)}$ 。また、Ohno らはPA を特発性アルドステロン症 (Idiopathic Hyperaldosteronism; IHA) およびアルドス テロン産生腫瘍(Aldosterone producing adenoma; APA) で区別して、年齢や血压を同じとした EHT との比較検 討を行っている。この検討における肥満(BMI $\geqq 25 \mathrm{~kg} /$ $\mathrm{m}^{2}$ ) 合併率は、EHT と APA で差は認めなかったのに対
して EHT と IHA では IHA が有意に高值であった。更 に、IHA と APAの比較においては BMI と肥満合併率 が IHA で有意に高值を示したことから、IHA の病因に 肥満が関与している可能性が考えられている ${ }^{5)}$ 。

肥満は、アルドステロンとの関連以外にも糖尿病をは じめとした様々な代謝異常を引き起こす。体重管理とし ては食事・運動療法が大前提となるが、高度肥満症では 奏功しない例が多く、結果的に肥満関連合併症の進行に よって患者の ADL が損なわれることがある。このよう な背景から、高度肥満症に対する有効な治療法として外 科手術が注目されている。手術は(1)摂食制限と(2)摃食制 限 + 吸収制限の 2 種類に大別され、本邦では平成 26 年 に(1)を主体とした LSG が保険収載されている。LSG は 胃の大弯側を切除することで、摂食を制限し減量効果を もたらす。効果としては(2)主体の腹腔鏡下ルーワイ胃バ イパス術(LRYGB)に及ばないものの(術後 1 年の体重減 少率 33\%、超過 BMI 減少率 83\%)、LSG においても体 重減少率 28\%、超過 BMI 減少率 72\% と良好な成績が 報告されている ${ }^{1)}$ 。減量と共に、糖尿病をはじめとする 様々な代謝異常の改善が報告されており、本邦の LSG における糖尿病の寛解率は $84.6 \%$ と非常に高い。また、 肥満・撕食行動の是正は高血圧に対しても有効であり、 その寛解率は $66 \%$ と報告されている(表 3)。

\section{表 3. 腹腔鏡下スリーブ胃切除 (LSG) の効果 ${ }^{1)}$ 一部改訂}

\begin{tabular}{|c|c|c|c|c|c|c|}
\hline & 症例数 & 罹患率 & 完全寛解 & 部分寛解 & 改善 & 不変 \\
\hline 2型糖尿病 & 65 & $\begin{array}{c}0.36 \\
(65 / 183)\end{array}$ & $\begin{array}{c}76.9 \% \\
(50 / 65) \\
\end{array}$ & $\begin{array}{c}7.7 \% \\
(5 / 65) \\
\end{array}$ & $\begin{array}{l}13.9 \% \\
(9 / 65) \\
\end{array}$ & $\begin{array}{c}1.5 \% \\
(1 / 65)\end{array}$ \\
\hline 高血圧 & 97 & $\begin{array}{c}0.53 \\
(97 / 183) \\
\end{array}$ & $\begin{array}{r}39.2 \% \\
(38 / 97) \\
\end{array}$ & $\begin{array}{c}26.8 \% \\
(26 / 97) \\
\end{array}$ & $\begin{array}{c}16.5 \% \\
(16 / 97) \\
\end{array}$ & $\begin{array}{c}17.5 \% \\
(17 / 97) \\
\end{array}$ \\
\hline 脂質異常症 & 94 & $\begin{array}{c}0.51 \\
(94 / 183)\end{array}$ & $\begin{array}{c}62.8 \% \\
(59 / 94)\end{array}$ & - & $\begin{array}{c}10.6 \% \\
(10 / 94)\end{array}$ & $\begin{array}{c}26.6 \% \\
(25 / 94)\end{array}$ \\
\hline \multicolumn{4}{|c|}{ 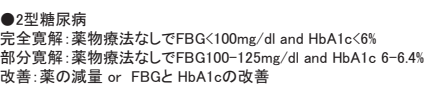 } & \multicolumn{3}{|c|}{ 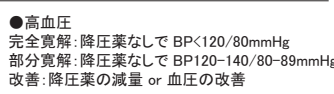 } \\
\hline
\end{tabular}

肥満の是正が高血圧に対して有効であることは明白で あるが、アルドステロンの自律分泌がどのように関連し ているかについては明らかとはなっていない。脂肪細胞 から分泌されるレプチン、アディポネクチンにより副 腎からのアルドステロン合成が促進されるとの報告 ${ }^{6}$ か ら、内臓脂肪の関与が想定されているが、確証には至っ ていない。

本症例は、肥満の是正により、塩化ナトリウム負荷に 対するアルドステロンの自律分泌の消失を認めており、 大変興味深い。副腎静脈サンプリングを施行していない ため、PA の病型診断はできていないが、肥満が IHA の 発症に関与している可能性を臨床的に示唆する貴重な症 例ではないかと考え、ここに報告した。 
結語

LSG による肥満の是正により塩化ナトリウム負荷に 対するアルドステロン自律分泌の消失を確認した一例を 経験した。肥満がアルドステロン自律分泌に関与してい ることを示唆する貴重な症例と考えられ、病態解明のた めにも更なる症例の蓄積が望まれる。

\section{文献}

1) Hidenori Haruta, Kazunori Kasama, Masayuki Ohta, Akira Sasaki, Hiroshi Yamamoto, Yasuhiro Miyazaki, Takashi Oshiro, Takeshi Naitoh, Yoshinori Hosoya, Takeshi Togawa, Yosuke Seki, Alan Kawarai Lefor, Toru Tani. Long-Term Outcomes of Bariatric and Metabolic Surgery in Japan: Result of a Multi-Institutional Survey. Obes Surg. 2017; 27: 754-62.

2) Francesco Fallo, Franco Veglio, Chiara Bertello, Nicoletta Sonino, Paolo Della Mea, Mario Ermani, Franco Rabbia, Giovanni Federspil, Paolo Mulatero. Prevalence and characteristics of the metabolic syndrome in primary aldosteronism. J Clin Endocrinol Metab. 2006; 91: 454-9.

3) Gregor Hanslik, Henri Wallaschofski, Anna Dietz, Anna Riester, Martin Reincke, Bruno Allolio, Katharina Lang, Ivo Quack, Lars C Rump, Holger S Willenberg, Felix Beuschlein, Marcus Quinkler, Anke Hannemann, participants of the German Conn's Registry. Increased prevalence of diabetes mellitus and the metabolic syndrome in patients with primary aldosteronism of the German Conn's Registry. Eur J Endocrinol. 2015; 173(5): 665-75.

4) Shigehiro Karashima, Takashi Yoneda, Mitsuhiro Kometani, Masashi Ohe, Shunsuke Mori, Toshitaka Sawamura, Kenji Furukawa, Takashi Seta, Masakazu Yamagishi, Yoshiyu Takeda. Hypertens Res. 2016; 39(3): 133-7.

5) Youichi Ohno, Masakatsu Sone, Nobuya Inagaki, Toshinari Yamasaki, Osamu Ogawa, Yoshiyu Takeda, Isao Kurihara, Hironobu Umakoshi, Takamasa Ichijo, Takuyuki Katabami, Norio Wada, Yoshihiro Ogawa, Takanobu Yoshimoto, Junji Kawashima, Minemori Watanabe, Yuichi Matsuda, Hiroki Kobayashi, Hirotaka Shibata, Shozo Miyauchi, Kohei Kamemura, Tomikazu Fukuoka, Koichi Yamamoto, Michio Otsuki, Tomoko Suzuki, and Mitsuhide Naruse, for the JPAS Study Group. Obesity as a Key Factor Underlying Idiopathic Hyperaldosteronism. J Clin Endocrinol Metab. 2018; 103: 4456-64.

6) Aurelia Nguyen Dinh Cat, Malou Friederich-Persson, Anna White and Rhian M Touyz. Adipocytes, aldosterone and obesity-related hypertension. J Mol Endocrin. 2016; 57: F7-21. 